\title{
PENGUKURAN KOEFISIEN DIFFUSE ATENUASI (Kd) DI PERAIRAN DANGKAL SEKITAR KARANG LEBAR, KEPULAUAN SERIBU, DKI JAKARTA
}

\section{MEASUREMENT OF DIFFUSE ATTENUATION COEFFICIENT (Kd) IN SHALLOW WATER ARROUND KARANG LEBAR, SERIBU ISLAND, DKI JAKARTA}

\author{
Budhi Agung Prasetyo ${ }^{1}$, Vincentius Paulus Siregar ${ }^{2}$, Syamsul Bahri Agus ${ }^{2}$, Wikanti Asriningrum ${ }^{3}$ \\ ${ }^{1}$ Program Studi Teknologi Kelautan, Fakultas Perikanan dan Ilmu Kelautan \\ ${ }^{2}$ Departemen Manajemen Sumberdaya Perairan \\ Fakultas Perikanan dan Ilmu Kelautan, Institut Pertanian Bogor \\ ${ }^{3}$ Pusat Pemanfaatan Penginderaan Jauh, \\ Lembaga Penerbangan dan Antariksa Nasional, Pekayon, Jakarta \\ Korespondensi: budhiagungp@gmail.com
}

\begin{abstract}
Diffuse attenuation coefficient from downwelling irradiance measurement is one of the important oceanography parameter that provide information on light availability and the light penetration through waters column that represent the waters clarity, photosynthesis and other biological processes. Information about diffuse attenuation coefficient play an important role on the development of bio-optical algorithm on Ocean Color satellite data. The aim of this research is to know the variability of diffuse attenuation coefficient in the shallow water of Karang Lebar, Air and Panggang island using irradiance sensor from hyperspectral radiometer TriOS-RAMSES covering a wavelength range from 320 to $950 \mathrm{~nm}$ with $3.3 \mathrm{~nm}$ spectral resolution. In situ measurments performed by pull down the irradiance sensor on each depth vertically in waters column up to just before the sea floor. Overall, the measurement result showed that values of $\operatorname{Kd}(\lambda)$ had patterns tends to be decreased on blue-green region wavelength (380-480 nm) and increased again on green-red region $(560-760 \mathrm{~nm})$. We found that values of $\mathrm{Kd}(\lambda)$ inside of gobah area had greater values than the outside gobah, significantly the difference significantly occured on all regions that $\operatorname{Kd}(\lambda)$ values measured $(F=5.581$ $>$ F critical $=5.554)$, where each regions has different characteristics to each others. $\operatorname{Kd}(\lambda)$ values dominantly affected by absorbtion of chlorophyll-a with determination cofficient R2 $=0.808$ compared with backscattering by suspended solid with determination coefficient $\mathrm{R} 2=0.043 \mathrm{Kd}(\lambda)$ values on visible wavelength regions $(400-700 \mathrm{~nm})$ can describe information about how far light can be detected by Ocean Color satellite from water column represented by one optical depth. Relationship of $\operatorname{Kd}(\lambda)$ values with one optical depth can be describe as exponential equation $\mathrm{Kd}(400$ $700 \mathrm{~nm})=0.6747 * \exp (-0.231 * 1 \zeta)$ with the determination coefficient $\mathrm{R} 2=0.97$.
\end{abstract}

Keyword: diffuse attenuation coefficient, downwelling irradiance, shallow water, optical depth

\section{ABSTRAK}

Nilai koefisien diffuse atenuasi $\operatorname{Kd}(\lambda)$ yang berasal dari pengukuran downwelling irradiance $\operatorname{Ed}(\lambda)$ merupakan salah satu parameter penting dalam oceanografi yang memberikan informasi mengenai ketersediaan cahaya dan tingkat penetrasi cahaya di dalam kolom air yang memberikan gambaran mengenai tingkat kecerahan, fotosintesis dan proses biologi lainnya. Informasi mengenai koefisien diffuse atenuasi memegang peranan penting dalam pengembangan algoritma BioOptik pada data satelit Ocean Color. Tujuan dari penelitian ini adalah untuk menjelaskan variabilitas dari koefisien diffuse atenuasi di perairan dangkal Karang Lebar, pulau Air dan Panggang dengan menggunakan sensor irradiace hyperspectral radiometer TriOS-RAMSES dengan cakupan rentang panjang gelombang 320 hingga $950 \mathrm{~nm}$ dengan resolusi spektral 3.3 nm. Pengukuran in situ dilakukan dengan menurunkan sensor irradiance di setiap kedalaman secara vertikal pada kolom air. Secara keseluruhan hasil pengukuran menunjukkan bahwa nilai $\operatorname{Kd}(\lambda)$ memiliki pola dimana pada region panjang gelombang 380-480 nm akan menurun dan akan meningkat kembali hingga pada region panjang gelombang merah 560-760 nm. Nilai $\mathrm{Kd}(\lambda)$ di bagian dalam gobah ditemukan lebih tinggi dibandingkan di bagian luar gobah dengan perbedaan yang signifikan terjadi di region panjang gelombang merah, perbedaan signifikan nilai $\operatorname{Kd}(\lambda)$ juga terjadi di ketiga wilayah $(\mathrm{F}=5.581>\mathrm{F}$ critical $=5.554)$ dimana masing-masing area memiliki karakteristik yang berbeda-beda. Secara dominan, nilai $\mathrm{Kd}(\lambda)$ dipengaruhi oleh serapan klorofil-a dengan $\mathrm{R} 2=0.808$ dibandingkan dengan hamburan dari muatan padatan terlarut dibuktikan dengan $\mathrm{R} 2=0.043$. Nilai $\mathrm{Kd}(\lambda)$ pada rentang panjang gelombang sinar tampak (400-700 nm) dapat memberikan gambaran mengenai jangkauan penetrasi cahaya sinar tampak yang bisa dideteksi oleh satelit dengan satuan satu kedalaman optik. Hubungan nilai $\mathrm{Kd}(\lambda)$ dengan satu kedalaman optik dijelaskan secara eksponensial dengan persamaan $\mathrm{Kd}(400-700 \mathrm{~nm})=0.375^{*} \exp \left(-0.095^{*} 1 \zeta\right)$ dengan koefisien determinasi $\mathrm{R} 2=0.97$.

Kata kunci: koefisien diffuse atenuasi, downwelling irradiance, perairan dangkal, kedalaman optik 


\section{PENDAHULUAN}

\section{Latar belakang}

Penggunaan teknologi inderaja pasif dalam bidang kelautan mengandalkan Rambatan Energi Elektromagnetik (REM) yang masuk ke dalam kolom air, hal tersebut memiliki kelemahan dimana REM akan mengalami pelemahan oleh sifat optik dari kolom air. Intensitas cahaya yang masuk kedalam kolom air akan mengalami proses absorbsi dan hamburan, yang kemudian disebut proses atenuasi, disebabkan oleh adanya komponen optik air yang menyebabkan menurunnya intensitas cahaya secara eksponensial dengan kedalaman kolom air. Proses atenuasi tersebut mengakibatkan REM yang kembali dari kolom air dan diterima oleh satelit atau sensor pada wahana penginderaan jauh telah mengalami berbagai interaksi yang terjadi pada kolom air dalam satuan meter (Groetsch 2011).

Koefisien diffuse atenuasi (Kd) merupakan properti optikyang penting dalam kajian kelautan dari bidang penginderaan jauh kelautan, terkait pelemahan REM di dalam kolom air. Selain itu nilai Kd adalah parameter kritis untuk membagi kelas kolom air (Jerlov 1976) untuk estimasi intensitas cahaya pada suatu kedalaman kolom air (Lee et al. 2005). Pengetahuan akan nilai Kd sangat berperan untuk mengetahui jangkauan pendeteksian kedalaman suatu kolom air yang berhubungan dengan kondisi optik perairan. Proses atenuasi memengaruhi penetrasi energi dalam kolom air secara eksponensial dengan kedalaman, maka dengan menggunakan hasil perhitungan koefisien atenuasi dari suatu wilayah di harapkan dapat memberikan informasi yang dapat digunakan dalam rangka meningkatkan akurasi pendeteksian informasi dari kolom air khususnya pada penginderaan jauh sinar tampak. Beberapa studi menyatakan bahwa pengaruh atenuasi dari kolom air merupakan ciri properti optik dari suatu wilayah perairan di Indonesia. Salah satu studi menyatakan bahwa perairan dangkal di sekitar gobah Karang Lebar dan pulau Panggang di Kepulauan Seribu, DKI Jakarta memiliki properti optik yang berbeda, sehingga pada saat penggunaan informasi dari citra satelit sinar tampak dari daerah tersebut memerlukan perlakuan terhadap kondisi properti optik dari masing-masing wilayah (Siregar \& Selamat 2010).

Parameter koefisien diffuse atenuasi (Kd) yang berasal dari pengukuran downwelling irradiance (Ed) merupakan salah satu parameter oseanografi penting yang berhubungan dengan ketersediaan dan penetrasi cahaya pada kolom air yang dapat memberikan informasi kecerahan perairan, proses fotosintesis, dan proses biologi lain yang berlangsung di laut (Kirk 2011; Jerlov 1976; Wang et al. 2008). Selain itu, nilai koefisien atenuasi diffuse juga merupakan salah satu gambaran dari properti perairan (Groetsch 2011). Untuk mengetahui properti optik dari badan air dalam kondisi teriluminasi cahaya dibutuhkan pengukuran spektral downwelling irradiance, $\operatorname{Ed}(\lambda)$ (Gege \& Pinnel 2011). Atenuasi mempengaruhi penetrasi energi dalam kolom air secara eksponensial dengan kedalaman. Dengan menggunakan hasil perhitungan koefisien atenuasi dari suatu wilayah di harapkan dapat memberikan informasi mengenai tingkat akurasi pendeteksian dengan menggunakan teknologi penginderaan jauh pasif sinar tampak. Sebelumnya telah banyak dilakukan penelitian untuk mengetahui properti optik dari suatu perairan dengan mengetahui nilai $\mathrm{Kd}$, yang kemudian digunakan sebagai gambaran keadaan perairan tersebut secara optik dengan mengetahui nilai $\mathrm{Kd}(490)$ yang digunakan sebagai input dalam pengembangan algoritma Ocean Color. Perairan Indonesia sendiri masih jarang dilakukan penelitian berkaitan dengan properti optik dengan mengetahui nilai $\mathrm{Kd}$, maka dari itu pada penelitian ini akan dilakukan pengukuran nilai koefisien diffuse atenuasi di perairan dangkal di sekitar area gobah Karang Lebar, Pulau Panggang dan Pulau Air secara optik. Pengetahuan tentang nilai Kd dapat digunakan sebagai informasi dasar untuk mengetahui keadaan kolom air secara optik, yang kemudian bisa digunakan sebagai informasi tentang jangkauan penetrasi cahaya yang dapat direkam oleh sensor satelit (satu kedalaman optik) (Kirk 2011; Mobley 1994). Penelitian ini bertujuan untuk mengetahui nilai koefisien diffuse atenuasi yang diukur dengan menggunakan sensor hyperspectral radiometer dan mengetahui karakteristik dan variabilitasnya di perairan dangkal disekitar area gobah Karang Lebar, pulau Panggang dan pulau Air, Kepulauan Seribu, DKI Jakarta. 


\section{METODE PENELITIAN}

Penelitian ini dilakukan di perairan dangkal dengan tipe dasar yang beragam yang terdiri dari habitat lamun, pasir dan terumbu karang dengan kedalaman yang bervariasi dengan rata-rata hingga $10 \mathrm{~m}$ dan paling dalam sekitar $30 \mathrm{~m}$ di sekitar pulau Air, pulau Panggang dan Karang Lebar (Gambar 1). Secara geografis lokasi penelitian terletak pada koordinat

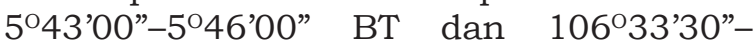
1063'30" LS. Titik pengukuran sampel di lapangan ditetapkan dengan menggunakan metode garis transek. Terdapat enam garis transek yang terdiri dari L1-L6. Penentuan titik sampling dari setiap garis transek ditentukan dengan menggunakan metode sampel random berstrata (stratified random sampling) dengan asumsi perairan dangkal di sekitar Karang Lebar memiliki beberapa kelompok tingkat kedalaman perairan di bagian tengah gobah, dibagian pinggir gobah dan dibagian luar gobah.

Pengukuran di lapangan dibagi menjadi dua bagian, yaitu pengukuran properti optik perairan dan pengukuran kualitas perairan. Pengukuran di lapangan dilakukan selama tiga hari pada tanggal 24 - 28 April 2016 dengan menggunakan kapal kecil dimulai sekitar pukul 09.00 hingga pukul 15.00 WIB dengan kondisi langit cerah dan dengan perairan yang tenang.

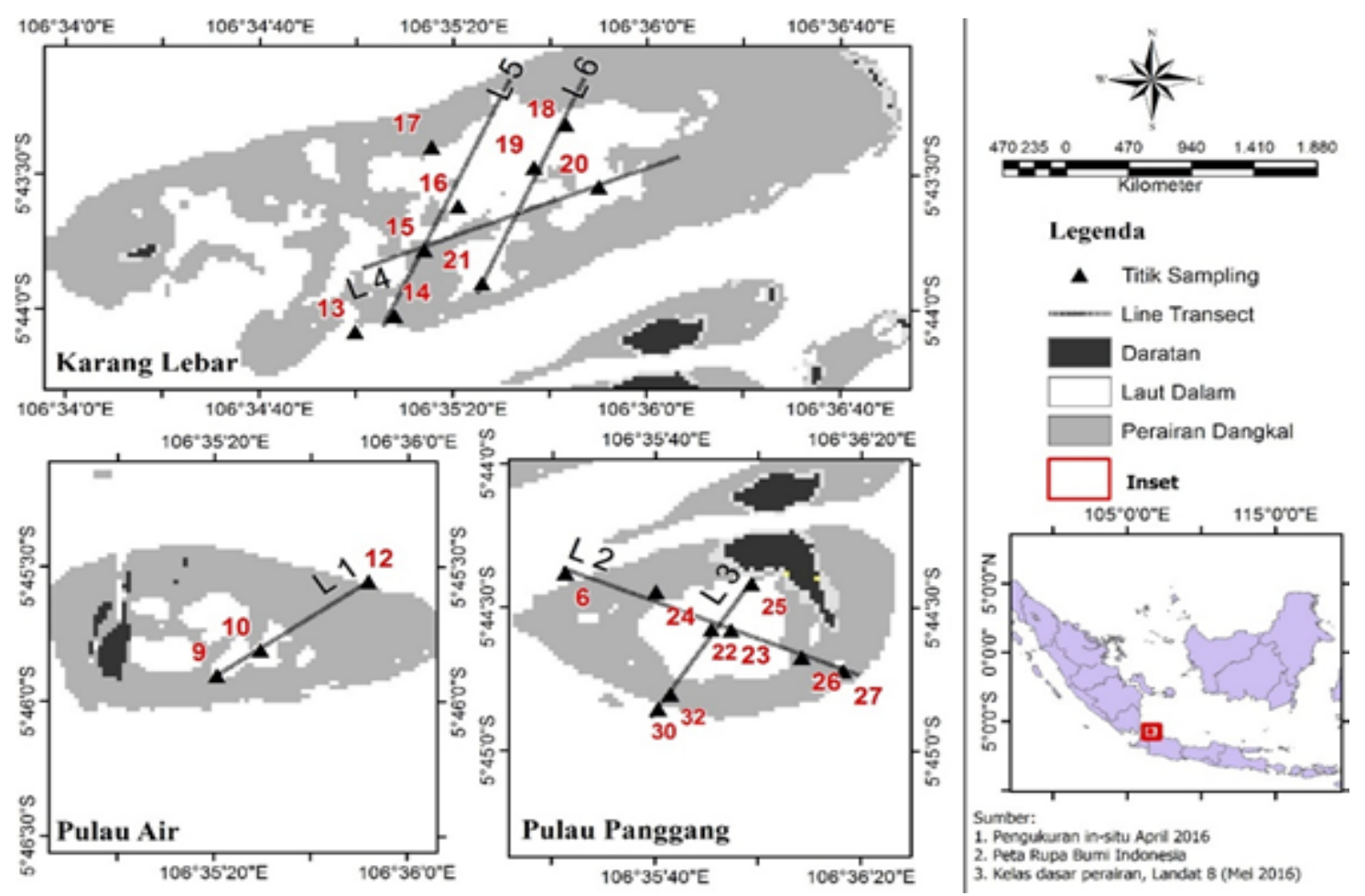

Gambar 1. Lokasi penelitian dan titik sampling

\section{Pengukuran sampel spektral downwelling irradiance (Ed) untuk perhitungan koefisien diffuse atenuasi (Kd)}

Pengukuran nilai spektral dilakukan dengan menggunakan perangkat hyperspectral radiometer TriOS-RAMSES dengan 190 kanal pada panjang gelombang $320-950 \mathrm{~nm}$ dan rentang kanal sebesar $3.3 \mathrm{~nm}$ dan perangkat komputer portable untuk akuisisi data spektral dari TriOS RAMSES. Nilai yang digunakan sebagai masukan untuk perhitungan nilai koefisien diffuse atenuasi adalah nilai downwelling irradiance, $\operatorname{Ed}(\lambda)$ yang direkam oleh sensor irradiance (ACC-2-VIS) TriOS-
RAMSES. Pengukuran dilakukan pada kedalaman tepat di bawah permukaan, Z1 dan di bawah air pada kedalaman Z2 dengan arah sudut sensor $90^{\circ} \mathrm{ke}$ arah zenith (Gambar 2).

Pencatatan data dilakukan di atas kapal dengan bantuan laptop dan perangkat akuisisi data dari TriOS-RAMSES. Data yang direkam kemudian disajikan dalam bentuk tabel dan grafik oleh software Multi Sensor Data Acquisition (MSDA_XE versi 8.9.2 2014-04-28) yang disediakan oleh TriOS $\mathrm{GmbH}$ dan secara radiometrik dikalibrasi dengan menggunakan calibration files untuk sensor downwelling irradiance (SAM_846B) 
untuk penggunaan sensor dalam air (aqua). Kalibrasi sensor dilakukan oleh LAPANPusfatja dengan menggunakan white reference dan dark reference panel yang disediakan oleh TriOs.

Data downwelling irradiance yang berasal dari software MSDA_XE kemudian di ekstrak menjadi file ASCII dengan format tab delimited, kemudian dilakukan sortir data dengan menggunakan perangkat lunak Microsoft Excel. Data Ed di setiap kedalaman kemudian di plot untuk dilakukkan curve fitting dengan menggunakan persamaan eksponensial dari data Ed tersebut. Nilai Kd sendiri dapat dihitung dengan menggunakan hasil pengukuran downwelling irradiance (Ed) pada dua kedalaman berbeda dengan menggunakan spektroradiometer pada downward irradiance pada kanal gelombang hiperspektral berpusat pada $\lambda$ dengan menggunakan rumus berikut (Kirk 2011) :

$$
K_{d}(\lambda)=\frac{1}{z_{2}-z_{1}} \ln \frac{E_{d}\left(z_{1}, \lambda\right)}{E_{d}\left(z_{2}, \lambda\right)}
$$

dimana, $z_{2}-z_{1}$ adalah selisih kedalaman pada pengukuran $(\mathrm{m})$ dan Ed adalah nilai downwelling irradiance pada kedalaman $z$ di panjang gelombang $\lambda$.

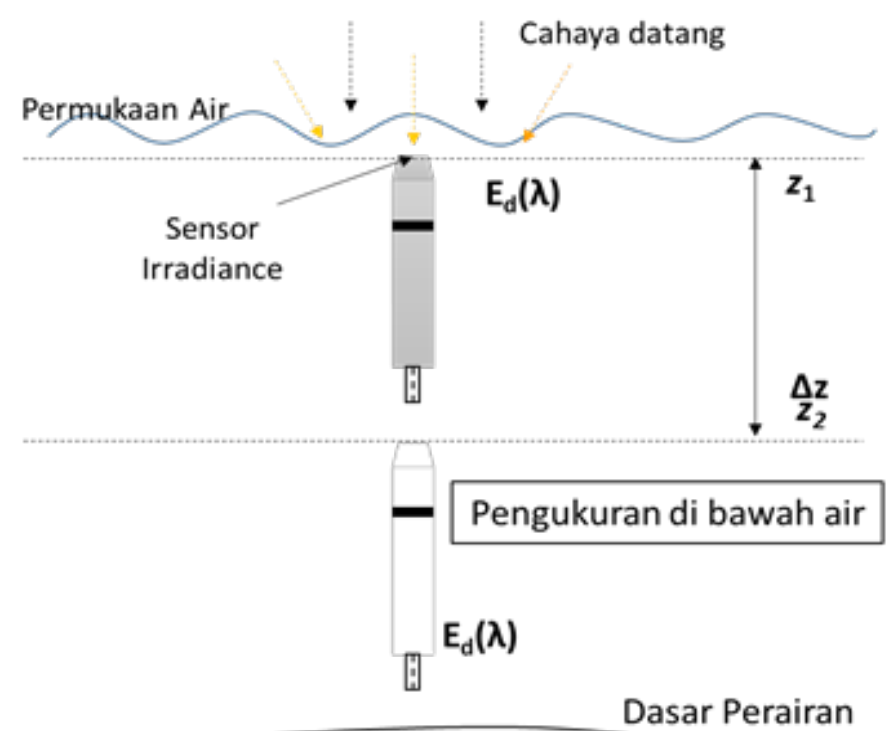

Gambar 2. Ilustrasi pengukuran downwelling irradiance (Ed) dengan irradiance sensor

\section{Pengambilan sampel kualitas perairan}

Pengambilan sampel air dilakukan bersamaan dengan pengukuran sampel spektral, kecerahan dan kedalaman perairan. Pengukuran kualitas perairan seperti klorofil-a dan muatan padatan terlarut (MPT) yang dilakukan pada penelitian ini digunakan untuk mengetahui seberapa besar pengaruh dari kandungan terlarut seperti klorofil-a yang merepresentasikan penyerapan (absorbtion) dan MPT yang merepresentasikan hamburan (scattering). Hasil pengukuran nilai Kd memberikan gambaran bahwa tingkat penetrasi cahaya dari masing-masing area berbeda-beda. Nilai Kd yang semakin kecil menunjukkan perairan yang makin cerah, dimana nilai $\mathrm{Kd}$ bergantung pada komposisi dari properti apparent optik badan air yang terdiri dari hamburan (scattering) dan penyerapan (absorbtion), sehingga komposisi bahan terlarut di dalam air memiliki pengaruh terhadap tingkat penetrasi cahaya (Kirk 2011).

Pengambilan sampel air dilakukan dengan menggunakan Van Dorn water sampler di setiap kedalaman, untuk dijadikan satu yang merepresentasikan sampel satu kolom air (bulk). Kemudian sampel air disimpan hingga kemudian dilakukan penyaringan. Sampel air sebanyak 2 liter disaring menggunakan membran filter. Kertas saring kemudian dimasukkan ke dalam botol kaca tertutup yang berisi $15 \mathrm{ml}$ larutan aseton 90\%. Botol sampel disimpan pada suhu $4^{\circ} \mathrm{C}$ selama 12 jam pada inkubator. Larutan yang keruh kemudian diputar dalam sentrifuge dengan kecepatan $5300 \mathrm{rpm}$ selama 2 x 5 menit sehingga larutan menjadi jernih dan endapannya terkumpul di dasar. Selanjutnya dianalisis 
dengan spektrofotometer.

Perhitungan konsentrasi klorofil-a dilakukan dengan mengukur absorbansi pada panjang gelombang 664, 647 dan 630 $\mathrm{nm}$. Perhitungan klorofil dihitung dengan persamaan sebagai berikut (APHA 2012):

dimana:

$$
\text { Klorofil }\left(\frac{m g}{l}\right)=\frac{C_{a} \times V_{a}}{C \times d}
$$

$\mathrm{Va} \quad=$ volume aseton $(\mathrm{ml})$

$V \quad=$ volume sampel air yang disaring (ml);

$d \quad=$ diameter cuvet;

$\mathrm{Ca}=(11.85 \times(\lambda, 664))-(1,54 \times(\lambda, 647))-$ $(0.08 \times(\lambda, 630))$;

Analisis suspensi terlarut sampel air sebanyak $200 \mathrm{ml}$ di ambil dari botol sampel kemudian disaring dengan menggunakan kertas saring Whatman Grade 934 AH dengan diameter pori $1.5 \mu \mathrm{m}$ yang sudah ditimbang terlebih dahulu berat keringnya. Setelah selesai penyaringan dengan kertas saring, selanjutnya kertas saring dimasukkan ke dalam oven yang dipanaskan pada suhu $105^{\circ} \mathrm{C}$ selama 1 jam. Setelah kering kemudian kertas saring dimasukkan ke dalam desikator kemudian ditimbang. Kemudian selisih perbedaan berat kertas saring dihitung menurut perhitungan APHA (2012) sebagai berikut:

$$
\operatorname{TSS} \frac{m g}{L}=\frac{(A-B) \times 1000}{\text { Volume sampel }(m L)}
$$

dimana:

A = berat kertas saring dengan suspensi terlarut kering (mg);

$B \quad=$ berat kertas saring tanpa suspensi terlarut kering (mg).

Pengukuran parameter kualitas perairan lainnya dilakukan dengan Water Quality Checker HANNA tipe HI 9828, untuk mengukur parameter seperti suhu dan salinitas, selain itu juga dilakukan pengukuran kedalaman perairan dengan menggunakan Sounder-Gun serta GPS digunakan untuk mencatat koordinat lokasi pengukuran.

\section{HASIL DAN PEMBAHASAN}

\section{Pengukuran kualitas air}

Hasil pengukuran kualitas perairan yang dilakukan di sekitar pulau Air, pulau Panggang dan Karang Lebar berupa data kedalaman perairan, kecerahan perairan, kandungan terlarut klorofil-a, dan kandungan terlarut muatan padatan (MPT) seperti pada Gambar 3. Dari ketiga area pengukuran kecerahan perairan, pulau Air memiliki nilai kecerahan perairan yang paling tinggi, kemudian di ikuti oleh Karang Lebar dan pulau Panggang (Tabel 1). Hasil pengukuran nilai $\mathrm{Kd}$ di dari ketiga area tersebut memberikan gambaran bahwa tingkat penetrasi cahaya dari masing-masing area berbeda-beda. Pengukuran kualitas perairan seperti klorofil-a dan muatan padatan terlarut (MPT) yang dilakukan pada penelitian ini digunakan untuk mengetahui seberapa besar pengaruh dari kandungan terlarut seperti klorofil-a yang merepresentasikan penyerapan (absorbtion) dan MPT yang merepresentasikan hamburan (scattering). Hasil pengukuran dari semua titik digambarkan dengan peta sebaran yang tertera pada Gambar 3.

Hasil pengukuran klorofil-a menunjukkan bahwa di sekitar perairan pulau Panggang lebih besar dibandingkan Karang Lebar yaitu $0.246 \mathrm{mg} / \mathrm{m}^{3}$ dan 0.203 $\mathrm{mg} / \mathrm{m}^{3}$, sedangkan rata-rata kandungan klorofil-a di sekitar pulau Air lebih kecil dari kedua daerah tersebut yaitu $0.137 \mathrm{mg} /$ $\mathrm{m}^{3}$. Aktivitas antropogenik di sekitar area pulau Panggang didominasi oleh adanya lalu lintas kapal dan aktivitas penduduk di pulau Panggang, sedangkan Karang Lebar dipengaruhi oleh adanya kegiatan budidaya ikan dengan menggunakan Keramba Jaring Apung, dimana aktivitas budidaya tersebut merubah kondisi kimia-fisika dan selanjutnya mengakibatkan berkembangnya fitoplankton karena perubahan konsentrasi nutrien (Jewel et al. 2003). Sekitar pulau Air tidak banyak terlihat adanya aktivitas antropogenik, hanya ada beberapa lalu lintas kapal wisata yang melalui daerah tersebut.

Hasil pengukuran muatan padatan terlarut (MPT) dari ketiga area di bagian tengah gobah pulau Air dan Panggang kandungan MPT relatif tinggi dibandingkan Karang Lebar (Gambar 3). Tingginya kandungan MPT di area pulau Panggang kemungkinan dipengaruhi oleh adanya aktivitas antropogenik dari pemukiman di sekitar pulau Panggang, sedangkan di gobah Karang Lebar kemungkinan dipengaruhi oleh rata-rata kedalaman perairan yang dangkal (Tabel 1) dan arus perairan sehingga terjadi pengadukan substrat dasar kemungkinan bisa terjadi lebih besar. 


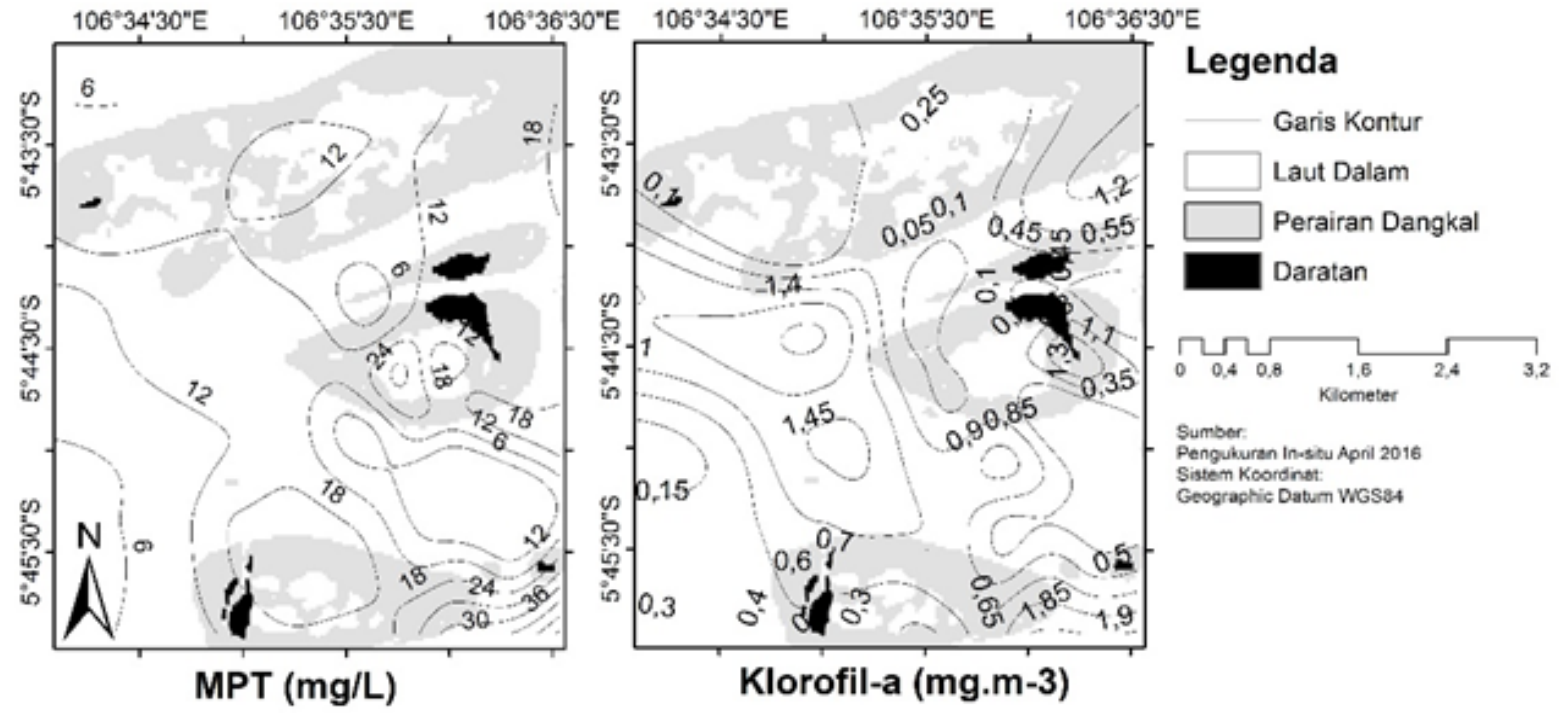

Gambar 3. Peta sebaran spasial kandungan klorofil-a dan MPT

\section{Analisis variabilitas nilai koefisien diffuse atenuasi $(\operatorname{Kd}(\boldsymbol{\lambda}))$}

Hasil pengukuran nilai Kd di ketiga area gobah dilakukan untuk mengetahui variabilitas properti optik dari ketiga area tersebut. Secara umum hasil pengukuran di setiap stasiun yang berada di gobah Karang Lebar juga memiliki pola yang sama seperti pulau Air dan pulau Panggang (Gambar 4), dimana pada area perairan semi-tertutup di bagian tengah gobah pulau dan di bagian yang dekat dengan pesisir memiliki rentang nilai $\operatorname{Kd}(\lambda)$ yang lebih besar. Fenomena tersebut dijelaskan oleh Brown et al. (2008) yang menyebutkan bahwa pada perairan terbuka properti optiknya cenderung lebih banyak dipengaruhi oleh kandungan organik seperti klorofil-a dibandingkan dengan kandungan inorganik seperti muatan padatan terlarut. Berbeda dengan di dalam daerah gobah dimana daerah tersebut cenderung dipengaruhi oleh partikel organik yang terperangkap di dalam gobah pulau.

Karakteristik dari nilai Kd di setiap area pada julat panjang gelombang hijau (500-550 nm), memiliki nilai Kd terendah dibandingkan di julat panjang gelombang biru dikarenakan pada panjang gelombang biru, atenuasi lebih dominan disebabkan adanya absorbsi oleh klorofil-a dan sel-sel fitoplankton serta molekul air (Gordon 1989; Lee et al. 2005). Julat panjang gelombang merah dominan dipengaruhi oleh absorbsi oleh molekul air murni (kedalaman), semakin dalam perairan semakin tinggi absorbsi di julat panjang gelombang merah (620-760 nm) (Mishra et al. 2005; Kirk 2011, Mobley 1994). Ketiga area diketahui pada area bagian dalam gobah memiliki rentang nilai $\mathrm{Kd}$ yang tinggi di julat panjang gelombang merah, yang disebabkan oleh adanya serapan dari molekul air dan kedalaman perairan, dimana di bagian tengah gobah pulau (stasiun 9, 10, 14, 20, 22, 24) ditemukan konsentrasi klorofil-a yang tinggi dan kedalaman perairan yang lebih dalam dibandingkan di bagian tepi gobah dengan dimana terdapat area perairan yang dangkal (Gambar 5). Rata-rata rentang Kd pada julat panjang gelombang merah di ketiga area berbeda secara signifikan secara statistik dengan uji analisis varians $(\mathrm{F}$ hitung $=5.581$ $>\mathrm{F}$ tabel $=5.554$ ) .

Sifat nilai $\operatorname{Kd}(\lambda)$ pada region panjang gelombang biru, hijau dan merah memiliki perbedaan dimana serapan dan hamburan terjadi di ketiga region panjang gelombang tersebut yang disebabkan oleh masingmasing faktor yang sudah disebutkan di atas. Untuk mengetahui perubahan nilai $\operatorname{Kd}(\lambda)$ di ketiga region panjang gelombang perlu diketahui kelas frekuensi nilai $\operatorname{Kd}(\lambda)$ pada masing-masing panjang gelombang. Berikut ini adalah grafik histogram ratarata nilai $\operatorname{Kd}(\lambda)$ di ketiga region panjang gelombang (Gambar 5). 

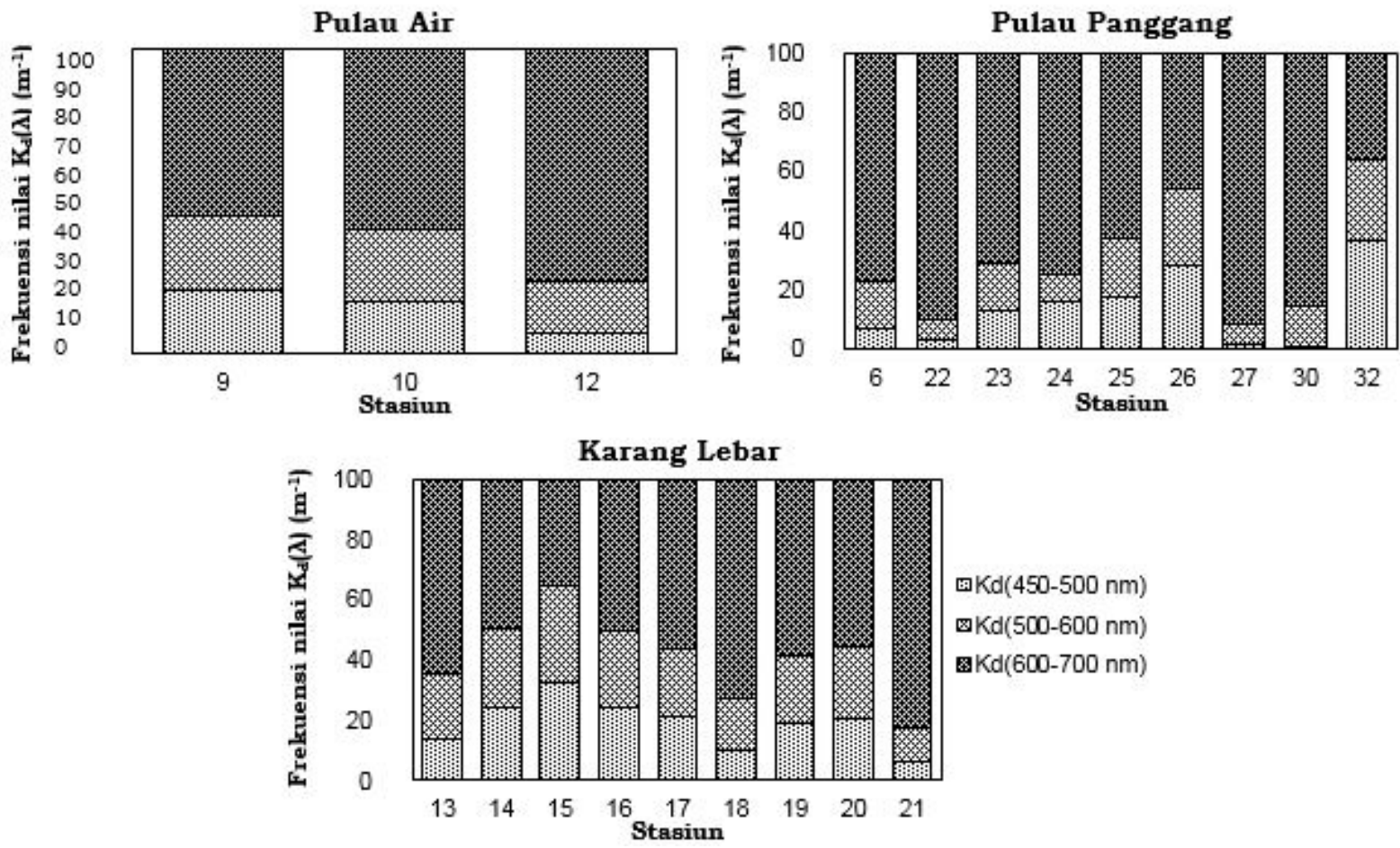

Gambar 4. Gambar histogram nilai $\operatorname{Kd}(\lambda)$ di region panjang gelombang biru, hijau dan merah di ketiga area pengukuran in-situ
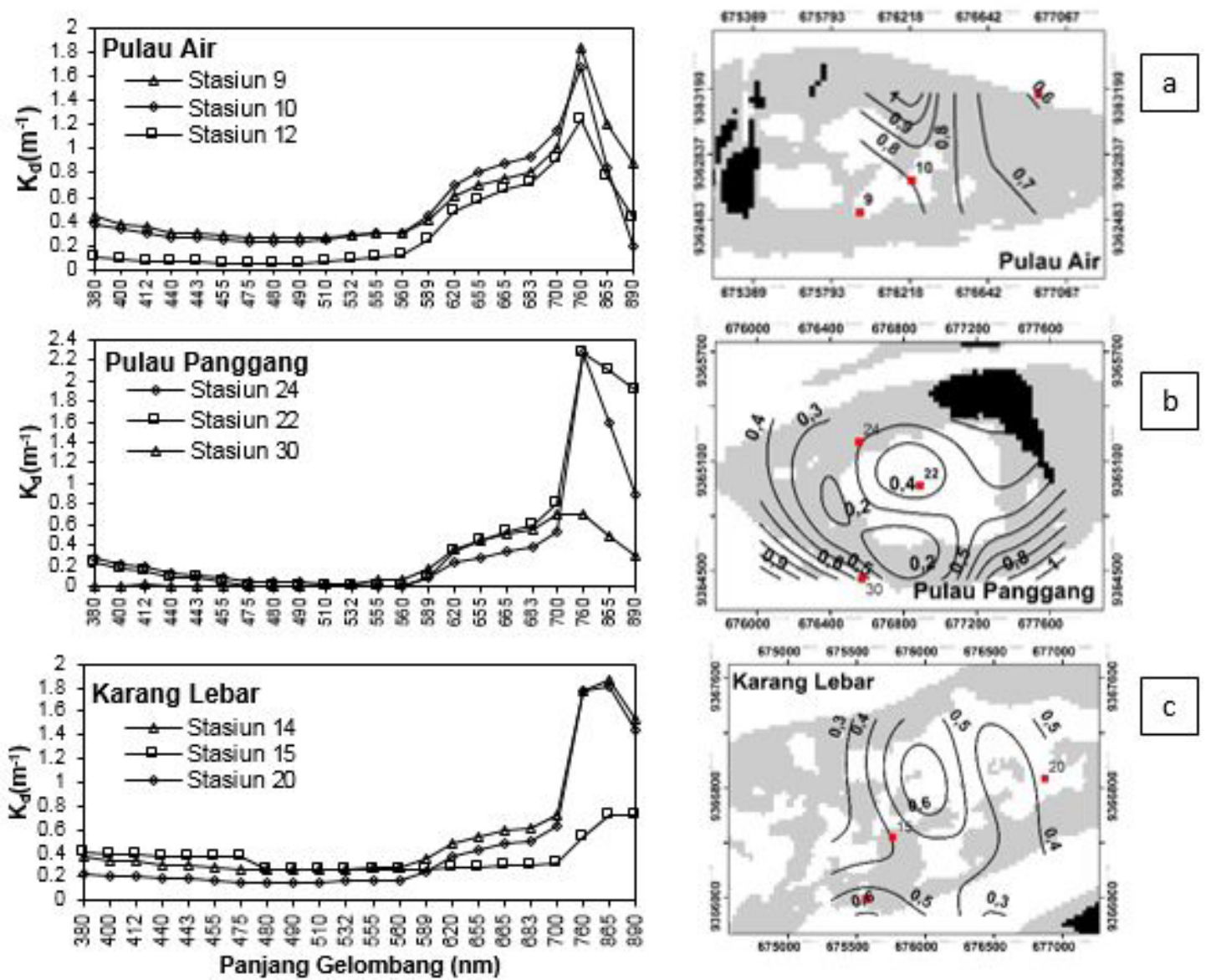

Gambar 4. Gambar hasil pengukuran $K d(\lambda)$ dan peta sebaran Kd pada julat panjang gelombang merah; a) Pulau Air; b) Pulau Panggang; c) Karang Lebar 


\section{Karakteristik optik berdasarkan nilai $\mathbf{K d}(\boldsymbol{\lambda})$}

Karakteristik optik dari pengukuran nilai Kd erat kaitannya dengan kemampuan sensor, khususnya sensor satelit dalam merekam radiansi yang kembali dari kolom air. Kemampuan sensor satelit dalam merekam radiansi hingga 90\% cahaya tersisa dari kolom air dengan persamaan yang diturunkan dari hukum Beer-Lambert dimana kemampuan sensor dalam merekam radiansi yang berasal dari satu lapisan kolom air disebut satu kedalaman optik dengan persamaan $1 \zeta=1 / \mathrm{K} \_\mathrm{d}(z, \lambda)$ (Nababan et al. 2013). Nilai Kd narrow band (400-700 $\mathrm{nm}$ ) memiliki hubungan secara eksponensial dengan kedalaman optik (Gambar 6), dimana semakin rendah nilai $\mathrm{Kd}$ akan semakin dalam nilai kedalaman optik dimana cahaya bisa penetrasi lebih jauh kedalam kolom air (Kirk 2011). Pola intensitas cahaya tersebut kemudian dapat digunakan sebagai informasi untuk menentukan lapisan kedalaman suatu perairan yang masih ditembus cahaya karena faktor terpenting dalam proses fotosintesis merupakan energi cahaya (Nuzapril et al. 2017).

Hasil perhitungan kedalaman optik dan rata-rata $\mathrm{Kd}(\lambda)$ dari masing-masing stasiun disajikan dalam Tabel 1. Jerlov (1976) menggunakan nilai $\operatorname{Kd}(\lambda)$ untuk membagi kelas pada perairan laut, dimana pada penelitian ini berdasarkan pembagian kelas kolom air Jerlov, pada area pulau Air dan pulau Panggang berada di tipe perairan IB sedangkan Karang Lebar berada di tipe perairan II. Tipe perairan I menurut Jerlov (1976) merupakan perairan dimana tingkat penyerapan dan hamburan energi cahaya hanya dipengaruhi oleh molekul air dan fitoplankton, sedangkan tipe II merupakan perairan yang dipengaruhi oleh padatan tersuspensi, padatan terlarut dan CDOM yang merubah warna perairan.

Hasil perhitungan satu kedalaman

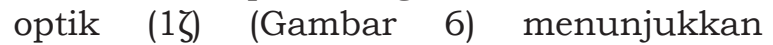
kemampuan cahaya dalam proses penetrasi kedalam kolom air hingga kembali ke sensor satelit, dimana semakin dalam kedalaman optik yang bisa diterima oleh sensor, semakin banyak informasi yang bisa di hasilkan oleh suatu citra satelit sinar tampak dan mengindikasikan tingkat kejernihan perairan (Jerlov 1976). Gambar 6 dapat memberikan informasi sampai sejauh mana sensor satelit khususnya satelit Ocean Color bisa mendeteksi kolom air di setiap rentang panjang gelombang. Nilai kedalaman optik dari ketiga area menunjukkan bahwa pulau Panggang memiliki satu stasiun dimana di daerah tersebut ditemukan pada saat pengukuran in-situ memiliki warna perairan yang jernih dengan substrat pasir dan lamun dengan kedalaman perairan ratarata $0.7-1 \mathrm{~m}$.

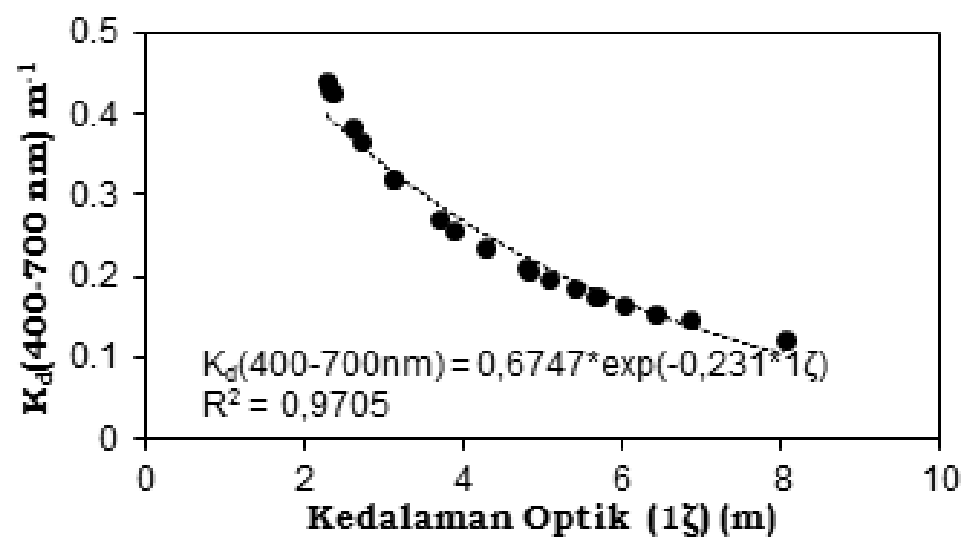

Gambar 6. Gambar hubungan $\mathrm{Kd}(400-700 \mathrm{~nm})$ dengan kedalaman optik 
Tabel 1. Rentang $\operatorname{Kd}(\lambda)$, rata-rata $\mathrm{Kd}(400-700 \mathrm{~nm})$ dan kedalaman optik di ketiga area

\begin{tabular}{lccc}
\hline Area & Stasiun & $\begin{array}{c}\text { Rata-rata Kd } \\
(\mathbf{4 0 0 - 7 0 0 ~} \mathbf{n m}) \mathbf{( m - 1 )}\end{array}$ & $\begin{array}{c}\text { Satu kedalaman optik (1 } \mathbf{~ \zeta ) ~} \mathbf{K d} \\
(\mathbf{4 0 0 - 7 0 0} \mathbf{~ n m})(\mathbf{m})\end{array}$ \\
\hline Pulau Air & 9 & 0.4261 & 2.3469 \\
& 10 & 0.4398 & 2.2733 \\
& 12 & 0.2353 & 4.2492 \\
\hline Pulau Panggang & 6 & 0.1777 & 5.6275 \\
& 22 & 0.1762 & 5.6746 \\
& 23 & 0.1861 & 5.3744 \\
& 24 & 0.1465 & 6.8270 \\
& 25 & 0,1244 & 8.0408 \\
& 26 & 0.3222 & 3.1038 \\
& 30 & 0.1559 & 6.4151 \\
& 32 & 0.2101 & 4.7604 \\
\hline Karang Lebar & 13 & 0.2707 & 3.6939 \\
& 14 & 0.3686 & 2.7128 \\
& 15 & 0.3849 & 2.5976 \\
& 16 & 0.4314 & 2.3178 \\
& 17 & 0.3203 & 3.1218 \\
& 18 & 0.1977 & 5.0588 \\
\hline
\end{tabular}

\section{Analisis hubungan koefisien diffuse atenuasi $(\mathrm{Kd}(\mathbf{\lambda}))$ dengan kualitas perairan}

Perairan dangkal memiliki karakteristik dimana kandungan klorofil-a dan MPT yang besar, sehingga sangat mempengaruhi proses serapan dan hamburan dari berkas energi cahaya yang memasuki kolom air (Saulquin et al. 2013). Nilai $\operatorname{Kd}(\lambda)$ sebagai bagian dari parameter AOP yang dipengaruhi oleh water constituent seperti kandungan klorofil-a dan padatan terlarut sebagai representasi dari absorbsi dan hamburan. Gordon (1989) menyebutkan bahwa nilai $\operatorname{Kd}(\lambda)$ dipengaruhi oleh koefisien absorbsi dari air laut dan distribusi dari medan cahaya. Hubungan secara linear terjadi pada nilai $\operatorname{Kd}(\lambda)$ pada rasio panjang gelombang $443 \mathrm{~nm}$ dan $555 \mathrm{~nm}$ dengan nilai klorofil-a, dengan persamaan $\mathrm{Kd}(443 / 555)$ = 2.774(Klorofil-a) +0.4537 dengan koefisien determinasi sebesar (R2) 0.8089. Stramska et al. (2003) menjelaskan bahwa nilai $\operatorname{Kd}(\lambda)$ pada julat panjang gelombang biruhijau memiliki hubungan dengan faktor absorbsi, dimana membuktikan bahwa nilai klorofil-a mampu menjelaskan nilai $\mathrm{Kd}(\mathrm{\lambda})$ sebesar $80.89 \%$ seperti ditunjukkan dalam Gambar 7a. Rasio band biru dan hijau meningkat seiring dengan bertambahnya konsentrasi klorofil-a dari perairan terbuka hingga ke perairan dangkal. Pada grafik rasio Kd (Gambar 7 a) pada gelombang biru dan hijau juga menunjukkan hal serupa, dimana kandungan klorofil-a mempengaruhi atenuasi di kolom air. Peningkatan nilai $\operatorname{Kd}(\lambda)$ juga mungkin dipengaruhi dari kontribusi partikel non-alga dan yellow substance. Ashraf et al. (2012) melakukan penelitian mengenai variasi vertikal dari $\operatorname{Kd}(\lambda)$ dan hubungannya dengan klorofil-a terjadi pada panjang gelombang pendek, dapat dijelaskan sebagai fungsi linear bahwa fitoplankton memiliki faktor penting dalam variabilitas $\mathrm{Kd}(\lambda)$, sedangkan untuk panjang gelombang yang lebih panjang (merah) cenderung dipengaruhi oleh absorbsi dari molekul air itu sendiri. Kandungan MPT kemungkinan bisa menambah hamburan cahaya di dalam kolom air dan meningkatkan nilai $\operatorname{Kd}(\lambda)$ (Gordon 1989).

Hubungan nilai $\operatorname{Kd}(\lambda)$ dengan muatan padatan terlarut tidak memiliki hubungan linear (Gambar 7 b). Hal tersebut dibuktikan dalam penelitian ini dimana nilai $\mathrm{Kd}(550)$ tidak memiliki hubungan yang siginifikan terhadap muatan padatan terlarut ditunjukkan oleh p-value $=0.378$ $>0.005$. Nilai Kd pada panjang gelombang $550 \mathrm{~nm}$ digunakan untuk menghitung koefisien hamburan untuk muatan padatan terlarut (Petzold 1972 dalam Budhiman et al. 2012), koefisien hamburan lebih dominan berpengaruh pada panjang gelombang yang lebih panjang $(>510 \mathrm{~nm})$ dan koefisien absorbsi lebih dominan berpengaruh terhadap nilai $\operatorname{Kd}(\lambda)$ pada panjang gelombang yang lebih pendek (Tiwari \& Shanmugam 2013).

Stramska et al. (2000) menyebutkan bahwa untuk mengetahui model hubungan yang lain antara pengukuran medan 
cahaya di dalam kolom air adalah dengan inherent optical properties (IOP), dimana nilai koefisien diffuse atenuasi (Kd) adalah nilai dari estimasi total koefisien absorbsi (a) dan total hamburan (bb) (Gordon 1975; Kirk 2011) atau sifat optik murni perairan laut yang ditentukan oleh spectral beam

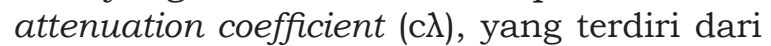
spectral absorbtion coefficient dan spectral backscattering coefficient (Susilo 2013). Penelitian ini tidak dilakukan perhitungan mengenai total koefisien absorbsi dan hamburan sehingga model radiatif transfer tersebut tidak dapat di aplikasikan untuk mengetahui karakteristik nilai koefisien diffuse atenuasi (Kd) khususnya pada total absorbsi dan hamburan dengan pendekatan IOP.
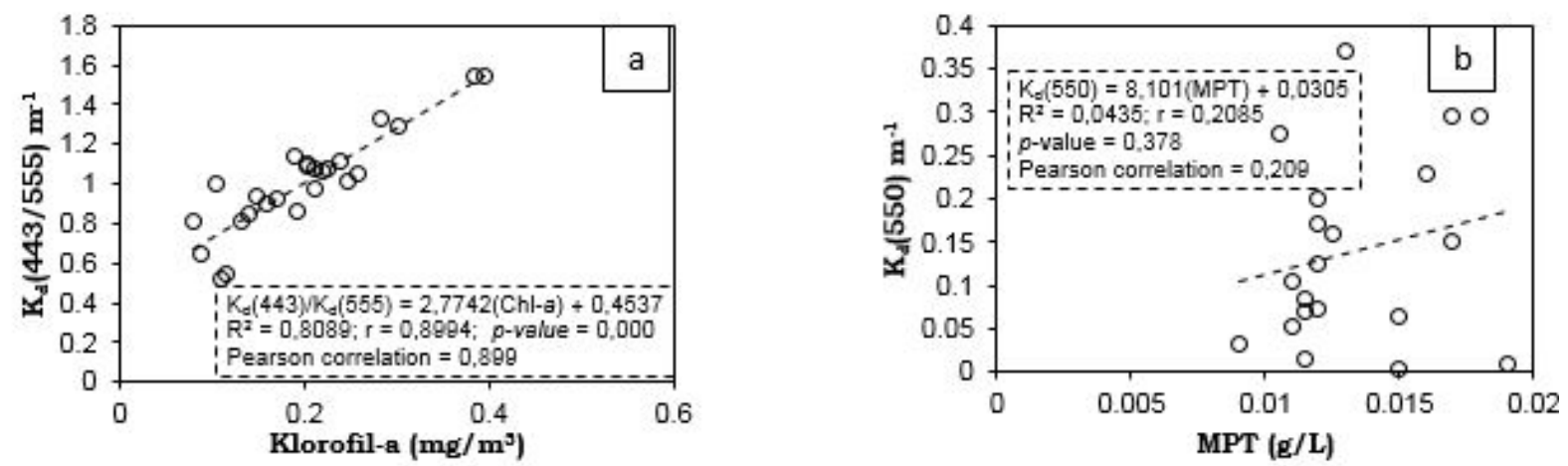

Gambar 7. Gambar hubungan variabel kualitas perairan dengan nilai $\mathrm{Kd}(\lambda)$

\section{KESIMPULAN DAN SARAN}

\section{Kesimpulan}

Karakteristik dari nilai Kd di setiap area pada julat panjang gelombang hijau (500-550 nm), memiliki nilai $\mathrm{Kd}$ yang terendah dibandingkan di julat panjang gelombang biru dikarenakan pada panjang gelombang biru, atenuasi lebih dominan disebabkan adanya absorbsi oleh klorofil-a dan sel-sel fitoplankton, sedangkan pada julat panjang gelombang merah dominan dipengaruhi oleh absorbsi oleh molekul air dan kedalaman. Hal tersebut ditunjukkan dengan grafik hubungan antara rasio nilai $\mathrm{Kd}$ pada panjang gelombang biru dan hijau dengan kandungan klorofil-a hasil pengukuran in-situ (Gambar 7a). Nilai Kd dari masing-masing area memiliki ciri perbedaan di rentang panjang gelombang merah. Dari ketiga lokasi pengukuran rentang $\mathrm{Kd}$ tertinggi terdapat di pulau Air $\left(\mathrm{Kd}(400-700 \mathrm{~nm})=0.440 \mathrm{~m}^{-1}\right)$ dan yang terendah terdapat di pulau Panggang $\left(\mathrm{Kd}(400-700 \mathrm{~nm})=0.124 \mathrm{~m}^{-1}\right)$. Jangkauan penetrasi cahaya yang dapat diterima sensor satelit dalam satu kedalaman optik dari ketiga area menunjukkan pulau Panggang memiliki titik dimana nilai satu kedalaman optiknya hingga $8.04 \mathrm{~m}$, dan nilai $\mathrm{Kd}$ juga memiliki pengaruh terhadap nilai satu kedalaman optik $(\mathrm{R} 2=0.97)$.

\section{Saran}

Saran untuk penelitian selanjutnya diperlukan analisis lebih lanjut mengenai total koefisien absorbsi dan hamburan dengan pendekatan inherent optical properties (IOP) dengan radiatif transfer model untuk lebih mengetahui profil dari interaksi cahaya di dalam kolom air serta diperlukan penelitan secara temporal nilai Kd agar dapat diketahui pola musiman dan faktor-faktor eksternal yang memengaruhinya.

\section{UCAPAN TERIMA KASIH}

Terima kasih diucapkan kepada Pusat Pemanfaatan Penginderaan Jauh LAPAN dan Bapak Syarif Budhiman, M.Sc yang telah memberikan izin untuk mengikuti kegiatan pengukuran data di Kepulauan Seribu, DKI Jakarta, memberikan masukan dan saran mengenai koefisien diffuse atenuasi dan penerapannya serta izin dalam penggunaan hyperspectral radiometer TriOS-RAMSES. 


\section{DAFTAR PUSTAKA}

Brown CA, Huot Y, Werdell PJ, Gentili B, Claustre H. 2008. The origin and global distribution of second order variability in satellite ocean color and its potential applications to algorithm development. J. Remote Sensing of Environment. Vol. 112:4186-4203.

Budhiman S, Salama MS, Vekerdy Z, Verhoef W. 2012. Deriving optical properties of Mahakam Delta coastal waters, Indonesia using in situ measurements and ocean color model inversion. ISPRS Journal of Photogrammetry and Remote Sensing 68: 157-169.

El-Otify AM. 2015. Evaluation of the physicochemical and chlorophyll-a conditions of a subtropical aquaculture in Lake Nasser area, Egypt. Beni-Suef University J. Basic and Applied Science 4:327-337.

Gege P. dan Pinnel C. 2011. Sources of variances of downwelling irradiance in water. J. Applied Optics Vol. 50 15:2192-2203

Gordon HR. 1975. Computed relationships between inherent and apparent optical properties of a flat, homogeneous ocean. J. Appl. Opt. 14:417-427.

Gordon HR. 1989. Can the Lambert-Beer law be applied to the diffuse attenuation coefficient of ocean water?. J. Limnol. Oceanogr. 34:1389-1409.

Gordon HR. 1991. Absorption and scattering estimates from irradiance measurement: Monte Carlo simulations. J. Limnol. Oceanogr. 36:769-777

Groetsch P. 2011. Optimization and verification of a new analytical radiative transfer model. [tesis]. Munchen (Germany): Deutschen Luftund Raumfahrtzentrum.

Jerlov NG. 1976. Marine Optics. Amsterdam (NED): Elsevier Scientific Publishing Company.

Kirk JTO. 2011. Light and Photosynthesis in Aquatic Ecosystem. Third Edition. Cambridge University Press.

Lee ZP, Carder KL, and Arnone RA, 2002, Deriving inherent optical properties from water color: A multiple quasianalytical algorithm for optically deep waters Applied Optics, 41(27):5,7555,772, doi:10. 1364/AO.41.005755.

Lee ZP, Darecki M, Carder KL, Davis CO, Stramski D, Rhea J. 2005. Diffuse attenuation coefficient of downwelling irradiance: An evaluation of remote sensing methods. Journal of Geophysical Research, Vol. 110, C02017.

Lee ZP, Du KP, Arnone R. 2005. A model for the diffuse attenuation coefficien of downwelling irradiance. Journal of Geophysical Research, Vol. 110, C02016.

Mishra DR, Narumalani S, Rundquist D, Lawson M. 2005. Characterizing the vertical diffuse attenuation coefficient for downwelling irradiances in coastal waters: Implications for water penetration by high resolution satellite data. Journal of Photogrammetry and Remote Sensing 60:48-64.

Mobley CD. 2001. Radiative Transfer in The Ocean. Squioia Scintific, Inc. WA, USA.

Nababan B, Louhenapessy VSA, Arhatin RE. 2013. Downwelling diffuse attenuation coefficients from in situ measurement of different water types. International Journal of Remote Sensing and Earth Sciences. Vol.10:122-133.

Nuzapril M, Susilo SB, Panjaitan JP. 2017. Hubungan antara konsentrasi klorofil-a dengan tingkat produktivitas primer menggunakan citra satelit Landsat 8. (In press).

Susilo SB. 2013. Penginderaan Jarak Jauh "Ocean Color". Departemen Ilmu dan Teknologi Kelautan. Fakultas Perikanan dan Ilmu Kelautan, IPB. Bogor.

Saulquin B, Hamdi A, Gohin F, Populus J, Mangin A, d'Andon OF. 2013. Estimation of the diffuse attenuation coefficient KdPAR using MERIS and application to seabed habitat mapping. $J$. Remote Sensing of Environment Vol 128:224-233.

Stramska M, Stramski D, Mitchell BG, Mobley CD. 2000. Estimation of the absorption and backscattering coefficients from in-water radiometric measurement. J. Limnol Oceanogr. 45(3):628-641.

Tiwari SP dan Shanmugam P. 2013. An optical model for deriving the spectral particulate backscattering coefficient in oceanic waters. J. Ocean Sci. Vol. 9: 987-1001.

Wang G, Cao W, Yang D, Xu D. 2008. Variation in downwelling diffuse attenuation coefficient in the northern South China Sea. Chinese Journal of Oceanology and Limnology Vol. 26: 323-333. 
Zaneveld JRV, Kitchen JC, Mueller JL. 1993. Vertical structure of productivity and its vertical integration as derived from remotely sensed obervation. J. Limnol. Oceanogr. 38:1384-1393.

Zheng $Z$, Ren J, Li Y, Huang C, Liu G, Du C, Lyu H. 2016. Remote sensing of diffuse attenuation coefficient patterns from Landsat 8 OLI imagery of turbid inland waters: A case study of Dongting Lake. $J$. Science of the Total Environment 573:39-54. 